\title{
ROBERTSONIAN TRANSLOCATION IN THE HOUSE MOUSE: A TALE OF CHROMOSOMAL SPECIATION
}

\author{
SILVIA GARAGNA (*), MAURIZIO ZUCCOTTI (**), \\ ERNESTO CAPANNA $(* * *)$, CARLOALBERTO REDI $(* * * *)$
}

SunTO. - Nella sottospecie Mus musculus domesticus sono state descritte numerose popolazioni in cui gli individui differiscono per il numero cromosomico. Tale variabilità dipende dalla presenza di un diverso numero di cromosomi metacentrici che derivano dalla fusione di cromosomi acro- o telocentrici nella regione del centromero. Questo tipo di traslocazione cromosomica viene definita fusione Robertsoniana. Dalla iniziale scoperta nel 1969 da parte di Alfred Gropp di individui con varianti cromosomiche nella valle svizzera di Poschiavo, più di 100 razze cromosomiche, in cui i metacentrici Robertsoniani sono fissati nella popolazione in omozigosi, sono state descritte in regioni geografiche estese in tutto l'ovest dell'Europa ed in particolare in Italia.

L'amicizia ed i comuni interessi scientifici tra Alfred Gropp, Ernesto Capanna e Maria Gabriella Manfredi Romanini hanno dato l'impulso a moltissimi studi proprio su quello che recentemente è stato definito il "fenomeno Robertsoniano". Questi studi hanno contribuito a comprendere: i) le basi molecolari della formazione dei cromosomi metacentrici, ii) la formazione delle diverse razze cromosomiche, iii) l'impatto esercitato dalla condizione di eterozigosi cromosomica sull'isolamento riproduttivo e sugli eventi di speciazione.

(*) Dipartimento di Biologia e Biotecnologie "Lazzaro Spallanzani"; Università degli Studi di Pavia, Via A. Ferrata 9, 27100 Pavia, Italy.

E-mail: silvia.garagna@unipv.it

${ }^{(* *)}$ Dipartimento di Scienze Biomediche, Biotecnologiche e Traslazionali; Università degli Studi di Parma, 43126 Parma, Italy.

(***) Dipartimento di Biologia e Biotecnologie "Charles Darwin"; Università di Roma "La Sapienza", Via Alfonso Borelli 50, 00161 Roma, Italy.

${ }^{(* * * *)}$ Dipartimento di Biologia e Biotecnologie "Lazzaro Spallanzani"; Università degli Studi di Pavia, Via A. Ferrata 9, 27100 Pavia, Italy. 
ABSTRACT. - The subspecies Mus musculus domesticus has a very high chromosome number variability for the presence, in different populations, of different numbers of metacentric chromosomes. These metacentrics are derived by Robertsonian fusion, i.e. the joining of two acro/telocentrics at the centromeres. Since the discovery in 1969 by Alfred Gropp of the first chromosomal variant in an isolated mouse population of the Swiss Poschiavo Valley, more than 100 geographically distinct chromosomal races with metacentrics fixed in homozygosity have been described. The friendship and the common scientific interests among Alfred Gropp, Ernesto Capanna and Maria Gabriella Manfredi Romanini have primed a wealth of studies on the "Robertsonian phenomenon" in this species. These studies have contributed to elucidate i) the molecular bases of metacentric chromosomes formation, ii) the establishment of metacentric races and iii) the impact that chromosome heterozygosities exert on reproductive isolation and speciation.

\section{THE DISCOVERY OF THE TOBACCO MOUSE}

The house mouse, Mus musculus domesticus, has a very high chromosome number variability for the presence, in different populations, of different numbers of metacentric chromosomes. These metacentrics are derived by Robertsonian $(\mathrm{Rb})$ fusion, i.e. the joining of two acro/telocentrics at the centromeres. Moreover, whole-arm reciprocal translocation (WART) has likely contributed to this extensive chromosomal diversification (Capanna and Redi, 1995; Piálek et al., 2005; Solano et al. (2007). Within West Europe and North Africa (i.e., the distribution area of this subspecies) over 100 geographically distinct chromosomal races with metacentrics fixed in homozygosity have been described. Their diploid number is comprised between the standard $2 \mathrm{n}=40$ (all telocentric) and $2 \mathrm{n}=22$ (nine pairs of metacentrics) chromosomes (Capanna, 1982; Piálek et al., 2005; Hauffe et al., 2012) and display contact areas in several geographic regions, generating hybrid zones where individuals may present high levels of structural chromosomal heterozygosity. The presence of $\mathrm{Rb}$ chromosomes in heterozygosity affects both the spermatogenetic and the oogenetic process, leading to reduced fertility or sterility. Chromosomal races may become reproductively isolated and, with time, they may undergo speciation.

Since the discovery in 1969 by Alfred Gropp of the first chromosomal variant in an isolated mouse population of the Swiss Poschiavo Valley (nicknamed Tobacco mouse, Fatio 1869) (Gropp et al., 1969), the house mouse has become one of the best known models of 'chro- 
mosomal speciation' (White, 1978; Capanna, 1982; King, 1993; Pialek et al., 2005; Capanna et al., 2009) for the role that chromosomal changes may exert in determining reproductive barriers. The friendship and the common scientific interests among Alfred Gropp, Ernesto Capanna and Maria Gabriella Manfredi Romanini have primed a wealth of studies on the "Robertsonian phenomenon" in the house mouse (Garagna et al., 2014) and the establishment at the Universities of Pavia and Rome of generations of pupils, including three of the authors of this review.

These studies have contributed to elucidate i) the molecular bases of metacentric chromosomes formation, ii) the establishment of metacentric races and iii) the impact that chromosome heterozygosities exert on reproductive isolation and speciation.

This paper is dedicated to the memory of professor Maria Gabriella Manfredi Romanini, and reviews the main scientific achievements that make the house mouse an impressive model species.

\section{THE MOLECULAR COMPOSITION AND ORGANISATION OF THE CENTROMERIC REGIONS MAKES THE MOUSE TELOCENTRIC CHROMOSOMES PRONE TO RB FUSION}

$\mathrm{Rb}$ translocation is the most diffused chromosome rearrangement in Mammals (Nguyen et al., 2008; Adega et al., 2009), and the house mouse has become a model species for the study of the molecular mechanisms of this mutation (Garagna et al., 1995; 2001; 2002; Nanda et al., 1995; Kalitsis et al., 2006; Cazaux et al., 2013). A comparative molecular analysis of the pericentromeric regions within eleven species and subspecies of the genus Mus, all with 2n=40 chromosomes, has evidenced a more homogeneous molecular composition and organisation of these regions of all the autosomes and the X chromosome in the Mus musculus domesticus subspecies (Redi et al., 1990; Garagna et al., 1993). It is this homogeneity that may determine the molecular background for the proneness of the house mouse chromosomes to $\mathrm{Rb}$ fusion (Redi et al., 1990; Garagna et al., 1993).

From the physical end towards the centromere of each telocentric and of the $\mathrm{X}$ chromosome the following families of repetitive DNA sequences are present: about 50-150 kb of telomeric sequences; a 1,780 bp truncated L1 (tL1) element; 1.8 to $15 \mathrm{~kb}$ of the TeLoCentric satellite 
(this satellite family is not present on each chromosome; Kalitsis et al., 2006; Cazaux et al., 2013); about 300-600 kb of minor satellite DNA (MinSat) (Kipling et al., 1991) and, more distantly, about 6 Megabases of major satellite DNA (MajSat) constitute the pericentromeric region and are involved in heterochromatin formation (Guenatri et al., 2004). Frequent exchange between non-homologous chromosomes is the likely mechanism of sequence conservation from the telomeric to the pericentromeric regions, and the head to tail orientation of the monomers (Wong and Rattner, 1988) sustains a base-pairing dependent mechanism of inter-chromosomal exchange between satellite sequences.

In the house mouse, translocation occurs in the centromeric regions. Following $\mathrm{Rb}$ fusion, the telomeric sequences and a relevant portion of the MinSat DNA are lost, and the newly formed centromeric region of the metacentric chromosome is made of about $50-70 \mathrm{~Kb}$ of MinSat, sandwiched between two blocks of MajSat DNA contributed by the two telocentrics (Garagna et al., 1995; 2001; Nanda et al., 1995). Fibre-FISH analysis confirmed, by direct visualisation of a discrete region of MinSat flanked by MajSat DNA on both sides, this organisation across the centromeric region of $\mathrm{Rb}$ metacentrics (Garagna et al., 2002). Both telocentrics involved in $\mathrm{Rb}$ translocation contribute with about 20-30 Kb each of MinSat sequences to the centromere, as shown by the contra-lateral symmetry of the signals observed using the chromosome oriented FISH (CO-FISH) procedure; also, the DNA polarity is maintained through the fusion point from one to the other chromosome arm of the newly formed $\mathrm{Rb}$ metacentric (Garagna et al., 2001). The conservation of this molecular organisation might allow WART, accelerating chromosomal evolution in the house mouse, as in the Aeolian archipelago in Sicily (Solano et al., 2009).

\section{RECOMBINATION SUPPRESSION AND GAMETOGENESIS IMPAIRMENT CONTRIBUTE TO POPULATION DIVERGENCE}

Different chromosomal races may come into contact generating "hybrid zones" where heterozygous mice are present. Heterozygotes are defined as "simple" when, during meiotic pairing, homologous chromosomes form trivalents, or "complex", when alternate arm homologies among different chromosomes leads to the formation of chain or ring meiotic figures. The presence of complex chromosome 
configurations may result in defective chromosomal pairing (Castiglia and Capanna, 2002; Wallace et al., 2002; Merico et al., 2003; 2013; Manterola et al., 2009) leading to non-disjunction (Searle, 1993; Everett et al., 1996; Eaker et al., 2001), and thus to the formation of aneuploid gametes (Gropp et al., 1982; Redi et al., 1984; 1985). Also, defective chromosomal pairing may trigger the apoptotic process in germ cells during both the male and female gametogenesis (Garagna et al., 1990; 2001; Merico et al., 2008; Manterola et al., 2009; Rodriguez et al., 2010). Studies on heterozygous mice, carrying translocations leading to the formation of a number of trivalents at meiosis I, have shown that apoptosis mainly occurs at metaphase I or metaphase II through, at least in part, a mitochondrial-dependent mechanism. (Merico et al., 2003; 2008; Manterola et al., 2009). The reduced or absent production of gametes that can carry aneuploidies cause either decreased fertility or complete sterility of heterozygous animals, thus reducing their reproductive fitness (Redi and Capanna, 1988; Hauffe and Searle, 1998; Castiglia and Capanna, 2000).

Chromosomal translocations may also exert effects on the frequency and distribution of chiasmata. In fact, lower number of recombination foci have been detected in both homozygous and heterozygous $\mathrm{Rb}$ than in all-telocentric mice (Bidau et al., 2001; Castiglia and Capanna, 2002; Dumas and Britton-Davidian, 2002; Merico et al., 2003; 2013).

In addition, the chiasma pattern along the rearranged chromosomes may be affected. While the frequency of proximal chiasmata tends to be lower in $\mathrm{Rb}$ than in telocentric bivalents, in trivalents the frequency of proximal and interstitial chiasmata increases (Bidau et al., 2001; Dumas and Britton-Davidian, 2002). On the contrary, when more complex meiotic figures (e.g., chains) are present, recombination foci are preferentially located in the terminal region of the chromosomes. Incompleteness or abnormalities of the pairing process at the centromere (likely due to pairing difficulties near the position of the chromosomal breakpoint of the heterozygous chromosomes) perhaps influence the reduction of the proximal recombination events, as shown by the shift towards the distal chromosome region (Merico et al., 2013). Thus, in the rearranged chromosomes, there seems to exist a mechanism of recombination suppression that plays a role in reducing chromosomal exchange. To this regard, the use of microsatellite for the assessment of the impact of chromosomal rearrangements on gene flow in a chromosomal hybrid zone between the Cittaducale chromosomal race $(2 n=22)$ and popula- 
tions with standard karyotype $(2 \mathrm{n}=40)$ in central Italy has confirmed that gene flow is lower at the centromere of all the tested $\mathrm{Rb}$ chromosomes (Franchini et al., 2010). If loci present in the centromeric regions are linked to "isolation genes", genetic diversification can be facilitated. The decrease and the shift towards the distal chromosome region of the recombination breakpoints ease the accumulation of genic differences that may contribute to reproductive isolation.

In summary, if we look back, forty-five years have passed since the description of the first $\mathrm{Rb}$ population; many important aspects have been clarified and many scientific achievements reached, but the story of the Tobacco mouse becomes everyday more and more intriguing and fascinating. To be continued...

\section{REFERENCES}

Adega F, Guedes-Pinto H, Chaves R. Satellite DNA in the karyotype evolution of domestic animals - clinical considerations. Cytogenet Genome Res 2009; 126:12-20.

Bidau C, Gimenez MD, Palmer CL, Searle JB. The effects of Robertsonian fusions on chiasma frequency and distribution in the house mouse (Mus musculus domesticus) from a bybrid zone in northern Scotland. Heredity 2001; 87:305-313.

Capanna E, Redi CA. Whole-arm reciprocal translocation (WART) between Robertsonian chromosomes: finding of a Robertsonian heterozygous mouse with karyotype derived through WARTs. Chromosome Res 1995; 3:135-137.

Capanna E. Robertsonian numerical variation in animal speciation: Mus musculus, an emblematic model. In: Mechanisms of Speciation. Barigozzi C, ed. Alan Liss: New York 1982: pp. 155-177.

Capanna E, Castiglia R, Solano E. Men and mice: mouse population genetics in the Aeolian archipelago. In: Life and Time: The Evolution of Life and its History. Casellato S, Burighel P, Minelli A, eds. Cleup: Padova 2009: pp. 59-74.

Castiglia R, Capanna E. Contact zone between chromosomal races of Mus musculus domesticus. 2. Fertility and segregation in laboratory-reared and wild mice beterozygous for multiple Robertsonian rearrangements. Heredity 2000; 85: 147-156.

Castiglia R, Capanna E. Chiasma repatterning across a chromosomal bybrid zone between chromosomal races of Mus musculus domesticus. Genetica 2002; 114:35-40.

Cazaux B, Catalan J, Justy F, Escudé C, Desmarais E, Britton-Davidian J. Evolution of the structure and composition of house mouse satellite DNA sequences in the subgenus Mus (Rodentia: Muridae): a cytogenomic approach. Chromosoma 2013; 122:209-220.

Dumas D, Britton-Davidian J. Chromosomal rearrangements and evolution of recombination: comparison of chiasma distribution patterns in standard and Robertsonian populations of the house mouse. Genetics 2002; 162:1355-1366. 
Eaker S, Pyle A, Cobb J, Handel MA. Evidence for meiotic spindle checkpoint from analysis of spermatocytes from Robertsonian-chromosome heterozygous mice. J Cell Sci 2001; 114:2953-2965.

Everett CA, Searle JB, Wallace BM. A study of meiotic pairing, nondisjunction and germ cell death in laboratory mice carrying Robertsonian translocations. Genet Res 1996; 67:239-247.

Franchini P, Colangelo P, Solano E, Capanna E, Verheyen E, Castiglia R. Reduced gene flow at pericentromeric loci in a bybrid zone involving chromosomal races of the house mouse Mus musculus domesticus. Evolution 2010; 64:2020-2032.

Garagna S, Broccoli D, Redi CA, Searle JB, Cook HJ, Capanna E. Robertsonian metacentrics of the house mouse lose telomeric sequences but retain some minor satellite DNA in the pericentromeric area. Chromosoma 1995; 103:685-692.

Garagna S, Marziliano N, Zuccotti M, Searle JB, Capanna E, Redi CA. Pericentromeric organization at the fusion point of mouse Robertsonian translocation chromosomes. Proc Natl Acad Sci USA 2001; 98:171-175.

Garagna S, Page J, Fernandez-Donoso R, Zuccotti M, Searle JB. The Robertsonian phenomenon in the house mouse: mutation, meiosis and speciation. Chromosoma 2014; 123:529-544.

Garagna S, Redi CA, Capanna E, Andayani N, Alfano RM, Doi P, Viale G. Genome distribution, chromosomal allocation and organisation of the major and minor satellite DNAs in eleven species of the genus Mus. Cytogenet Cell Genet 1993; 64:247255.

Garagna S, Redi CA, Zuccotti M, Britton-Davidian J, Winking H. Kinetics of oogenesis in mice beterozygous for Robertsonian translocation. Differentiation 1990; 42:167-171.

Garagna S, Zuccotti M, Capanna E, Redi CA. High-resolution organization of mouse telomeric and pericentromeric DNA. Cytogenet Genome Res 2002; 96:125-129.

Gropp A, Winking H, Redi CA, Capanna E, Britton-Davidian J, Noack G. Robertsonian karyotype variation in wild house mice from Rhaeto-Lombardia. Cytogenet Cell Genet 1982; 34:67-77.

Gropp A, Tettenborn U, and von Lehmann E. Chromosomenuntersuchungen bei der Tabakmaus (M. poschiavinus) und bei den Hybriden mit der Laboratorumsmaus. Experientia 1969; 25:875-876.

Guenatri M, Bailly D, Maison C, Almouzni G. Mouse centric and pericentric satellite repeats form distinct functional heterochromatin. J Cell Biol 2004; 166:493-505.

Hauffe HC, Giménez MD, Searle JB. Chromosomal hybrid zones in the house mouse. In Evolution of the House Mouse (Cambridge Series in Morphology and Molecules). Macholán M, Baird SJE, Munclinger P, Piálek J. eds. Cambridge University Press: Cambridge 2012: pp. 407-430.

Hauffe HC, Searle JB. Chromosomal beterozygosity and fertility in bouse mice (Mus musculus domesticus) from Northern Italy. Genetics 1998; 150:1143-1154.

Kalitsis P, Griffiths B, Choo KHA. Mouse telocentric sequences reveal a high rate of homogenization and possible role in Robertsonian translocation. Proc Natl Acad Sci USA 2006; 103:8786-8791. 
King M. Species Evolution: The Role of Chromosome Change. Cambridge University Press: Cambridge 1993.

Kipling D, Ackford HE, Taylor BA, Cooke HJ. Mouse minor satellite DNA genetically maps to the centromere and is physically linked to the proximal telomere. Genomics 1991; 11:235-241.

Manterola M, Page J, Vasco C, Berrios S, Parra MT, Viera A, et al. A bigh incidence of meiotic silencing of unsynapsed chromatin is not associated with substantial pachytene loss in heterozygous male mice carrying multiple simple Robertsonian translocations. PLoS Genet 2009; 5, e1000625.

Merico V, de Barboza GD, Vasco C, Ponce R, Rodriguez V, Garagna S, et al. A mitochondrial mechanism is involved in apoptosis of Robertsonian mouse male germ cells. Reproduction 2008; 135:797-804.

Merico V, Giménez MD, Vasco C, Zuccotti M, Searle JB, Hauffe HC, et al. Chromosomal speciation in mice: a cytogenetic analysis of recombination. Chromosome Res 2013; 21:523-533.

Merico V, Pigozzi MI, Esposito A, Merani MS, Garagna S. Meiotic recombination and spermatogenic impairment in Mus musculus domesticus carrying multiple simple Robertsonian translocations. Cytogenet Genome Res 2003; 103:321-329.

Nanda I, Schneider-Rasp S, Winking H, Schmid M. Loss of telomeric sites in the chromosomes of Mus musculus domesticus (Rodentia: Muridae) during Robertsonian rearrangements. Chromosome Res 1995; 3:399-409.

Nguyen TT, Aniskin VM, Gerbault-Seureau M, Planton H, Renard JP, Nguyen BX, et al. Phylogenetic position of the saola (Pseudoryx nghetinhensis) inferred from cytogenetic analysis of eleven species of Bovidae. Cytogenet Genome Res 2008; 122: 41-54.

Piálek J, Hauffe HC, Searle JB. Chromosomal variation in the house mouse. Biol J Linn Soc 2005; 84:535-563.

Redi CA, Garagna S, Pellicciari C, Manfredi Romanini MG, Capanna E, Winking H, et al. Spermatozoa of chromosomally beterozygous mice and their fate in male and female genital tracts. Gamete Research 1984; 9:273-286.

Redi CA, Capanna E. Robertsonian beterozygotes in the bouse mouse and the fate of their germ cells. In: The Cytogenetics of Mammalian Autosomal Rearrangements. Daniel A ed. Alan Liss: New York 1988: pp. 315-359.

Redi CA, Garagna S, Della Valle G, Bottiroli G, Dell'Orto P, Viale G, et al. Differences in the organization and chromosomal allocation of satellite DNA between the European long tailed bouse mice Mus domesticus and Mus musculus. Chromosoma 1990; 99:11-17.

Redi CA, Garagna S, Hilscher B, Winking H. The effects of some Robertsonian chromosome combinations on the seminiferous epithelium of the mouse. J Embryol Exp Morphol 1985; 85:1-19.

Rodriguez V, Diaz de Barboza G, Ponce R, Merico V, Garagna S, Tolosa de Talamoni N. Spermatocyte apoptosis, which involves both intrinsic and extrinsic pathways, explains the sterility of Graomys griseoflavus $x$ Graomys centralis male bybrids. Reproduction, Fertility and Development 2010; 22:1-11. 
Searle JB. Chromosomal bybrid zones in eutherian mammals. In: Hybrid Zones and the Evolutionary Process. Harrison RG ed. Oxford University Press: New York 1993: pp. 309-353.

Solano E, Castiglia R, Capanna E. Chromosomal evolution of the house mouse, Mus musculus domesticus, in the Aeolian Archipelago (Sicily, Italy). Biol J Linn Soc 2009; 96:194-202.

Solano E, Castiglia R, Corti M. A new chromosomal race of the house mouse, Mus musculus domesticus, in the Vulcano Island-Aeolian Archipelago, Italy. Hereditas 2007; 144:75-77.

Wallace BMN, Searle JB, Everett CA. The effect of multiple simple Robertsonian heterozygosity on chromosome pairing and fertility of wild-stock bouse mice (Mus musculus domesticus). Cytogenet Genome Res 2002; 96:276-286.

White MJD. Chain processes in chromosomal speciation. Systematic Zoology 1978; 27:285-298.

Wong AK, Rattner JB. Sequence organization and cytological localization of the minor satellite of mouse. Nucleic Acids Res 1988; 16:11645-61. 